\title{
Makarenko D. \\ EVALUATION OF THE EFFECT OF INDUSTRIAL ENTERPRISES ON THE ENVIRONMENT AND EFFICIENCY EVALUATION OF ENVIRONMENTAL PROTECTION ON THE EXAMPLE OF "KHARKIV ELECTROMECHANICAL PLANT» SE (UKRAINE)
}

Розвиток науково-технічного прогресу поряд із загальним поліпшенням якості життя людей має найпотужніший техногенний вплив на навколишнє природне середовище. Для зниження шкідливого впливу на навколишн середовище необхідно вирішувати питання ефективного очищення та нормування викидів, розрахунків гранично допустимих викидів. Тому об'єктом дослідження є вплив промислового підприємства на довкілля. Одним з джерел забруднення природного навколищнього середовища є підприємства машинобудівного комплексу. Тому на прикладі одного із них проведено оиінку впливу на навколишнє середовище на прикладі Державного підприємства «Харківський електромеханічний завод» (Україна). А також розроблено пропозиції по впровадженню відповідних природоохоронних заходів.

Як і на більшості промислових підприємств, на Державному підприємстві «Харківський електромеханічний завод» утворюються тверді відходи, забруднені зливові стоки та газоподібні викиди в атмосферу. У зв'язку з тим, що підприємство знаходиться в межах міста, до нвого пред'являються відповідні вимоги з охорони навколишнього середовища. Господарська діяльність підприємства супроводжується виконанням вимог екологічної безпеки, охорони здоров'я населення, планування заходів з охорони навколишнього середовища та ращіонального використання природних ресурсів.

В роботі була проведена оцінка впливу Державного підприємства «Харківський електромеханічний завод» на навколишн середовище та загальної характеристики району розміщення підприємства. Також були проаналізовані природно-кліматичні та метеорологічні умови території та приведена оцінка стану навколищнъого середовища. В роботі виявлені джерела забруднення технологічного процесу виробництва підприємства. Показано, що з 131 джерела викиду 20 джерел оснащені газоочисними установками. Аналіз впливу виявлених джерел на довкілля показав, що необхідно застосовувати газоочисні установки для очищення викидів до атмосферного повітря, а також те, що викиди підприємства в цілому не перевищують допустимих нормативів.

Проведені дослідження стануть в нагоді для реалізації природоохоронних заходів на підприємствах різних галузей, які є джерелами викидів потениійно-небезпечних речовин.

Ключові слова: викиди промислових об'єктів, техногенний вплив, системи очищення, забруднення довкілля, навколишнє середовище.

Received date: 14.02 .2020

Accepted date: 17.03 .2020

Published date: 30.06 .2020
Copyright (C) 2020, Makarenko D. This is an open access article under the CC BY license (http://creativecommons.org/licenses/by/4.0)

\section{Introduction}

The development of scientific and technological progress, along with a general improvement in the quality of life of people, has an environment of powerful technogenic impact. First of all, this is expressed in air pollution, unsatisfactory quality of drinking water, soil pollution and waste accumulation. The production of electrical products is accompanied by a significant release of pollutants into the environment. All these pollutants during operation, getting into the atmosphere, in water basins and in the soil significantly worsen the environmental situation. To reduce the harmful effects on the environment, it is ne- cessary to solve the issue of effective cleaning and regulation of emissions, calculation of maximum permissible emissions [1, 2]. The nature of the destructive effect of biosphere pollution on humans can be different. This, for example, the toxic effect of chemicals that lead to poisoning of the body, organ trauma (skin, vision, hearing, etc.). A number of substances can cause allergies. Some substances and radiation are carcinogenic or mutagenic, that is, they can cause cancer or genetic pathology [3-5]. In [6], it is noted that enterprise emissions are an important component of both environmental well-being and economic stability. The authors of the study [7] believe that it is the increase in emissions, especially carbon, characteristic of developing 
countries. The study [8] analyzes the sources of the greenhouse effect enhancement, among which emissions from industrial enterprises occupy a significant place.

One of the sources of environmental pollution is the enterprises of the engineering complex. Therefore, on the example of one of them, an environmental impact assessment will be carried out - on the example of the State Enterprise «Kharkiv Electromechanical Plant» («KhEMP» SE, Ukraine). Thus, the object of research is the impact of an industrial enterprise on the environment. The aim of research is to assess the impact of an industrial enterprise on the environment and the effectiveness of environmental protection measures on the example of «KhEMP» SE.

\section{Methods of research}

«KhEMP» SE produces equipment for the energy, coal mining, metallurgical, chemical, engineering and shipbuilding industries. The company specializes in the production of electrical machines, low-voltage equipment and low-voltage complete devices, control station systems, components for machines and stations, thyristor converters, circuit protection monitoring equipment [9]. The main source of air pollution at the «KhEMP» $\mathrm{SE}$ is air handling units that remove contaminated air from the technological equipment of production sites, as well as from auxiliary units and services. Also the sources of pollution are:

1) machine shop, where the products are painted in the paint chamber, digestion with hydrochloric acid and tinning of copper parts;

2) hardware-station shop, where plating, soldering and welding, tinning of parts, as well as painting of parts are carried out, negatively affects the environment;

3) mechanical repair shop where the sharpening of the cutting tool, grinding of steel products and gas welding and gas cutting works, welding with electrodes are carried out, which are sources of pollution;

4) electric shop where electric welding in a welding cabin; impregnation of the winding of electric motors with subsequent annealing of insulation in an electric furnace, painting of electric motors are carried out, which negatively affects the environment;
5) tool shop, where metal cutting, thermal annealing of steel, heat treatment of steel in furnaces, grinding of steel products, welding are carried out, which negatively affects the environment;

6) production packaging shop, where the source of pollution is dust from woodworking machines;

7) model woodworking shop where wooden models for foundry are made and spray boards are used, which are a source of dust pollution;

8) motor vehicle shop where the source of air pollution is internal combustion engines, which are emitted into the atmosphere when heated: carbon oxide, saturated hydrocarbons, nitrogen dioxide, soot, sulfur dioxide, lead, benzo(a)pyrene.

According to the degree of danger, substances are divided into 4 classes. With pollutants emitted by the enterprise into the atmosphere, lead and benzo(a)pyrene are classified as hazard class I.

«KhEMP»SE refers to the IV category of danger. There are no accidental and volley emissions at the enterprise. Landfills and landfills for industrial solid waste are not available at the «KhEMP» SE.

The company does not have its own landfill. The removal of industrial waste should be carried out according to the permission of the city sanitary-epidemiological station.

According to the appendix 4 to the State Sanitary Rules for the Planning and Development of Settlements [10], the regulatory sanitary protection zone (SPZ) for industrial site of «KhEMP» SE is $100 \mathrm{~m}$.

Since the object is a large enterprise, it accordingly emits various kinds of impurities in large volumes (Table 1). 131 sources of pollutant emissions into the atmosphere are allocated from all the shops of the enterprise. Of these, 130 are stationary sources, one source (No. 131) is nonstationary.

Data on the concentration of pollutants in the wastewater of «KhEMP» SE when discharged into the city sewer network are presented in Table 2.

Therefore, as can be seen, the excess of the permissible values given in [11, 12] does not occur.

At the «KhEMP» SE, retail waste is generated in the production process. Their characteristics are given in Table 3.

List of pollutants released into the atmosphere

\begin{tabular}{|c|c|c|c|}
\hline No. & Substance name & Hazard Class & Gross emission, $t /$ year \\
\hline 1 & 2 & 3 & 4 \\
\hline 1 & nitrogen dioxide & 2 & 0.442 \\
\hline 2 & nitric oxide & 3 & 2.400 \\
\hline 3 & sulphurous hydride & 3 & 0.0042 \\
\hline 4 & carbon monoxide & 4 & 5.250 \\
\hline 5 & benzo(a)pyrene & 4 & 0.000385 \\
\hline 6 & sparingly soluble fluorides & 2 & 0.00092 \\
\hline 7 & silicon oxide & 5 LLI 0.02 & 0.00092 \\
\hline 8 & hydrogen fluoride & 2 & 0.00476 \\
\hline 9 & phenol & 2 & 0.0094 \\
\hline 10 & formaldehyde & 2 & 0.0050 \\
\hline 11 & lead & 1 & 0.01840 \\
\hline 12 & tin oxide & 3 & 0.0289 \\
\hline
\end{tabular}


Continuation of Table 1

\begin{tabular}{|c|c|c|c|}
\hline 1 & 2 & 3 & 4 \\
\hline 13 & hydracarbons [12-[19 & 4 & 0.0115 \\
\hline 14 & soot & 3 & 0.8717 \\
\hline 15 & iron oxide & 3 & 0.5581 \\
\hline 16 & manganese oxide & 2 & 0.0262 \\
\hline 17 & aerosol oil & SRLI 0.05 & 0.2459 \\
\hline 18 & sulfuric acid & 2 & 0.5025 \\
\hline 19 & toluene & 3 & 18.2455 \\
\hline 20 & ethanol & 4 & 18.1150 \\
\hline 21 & aerosol & SRLI 0.1 & 1.2991 \\
\hline 22 & solvent & SRLI 0.2 & 2.7680 \\
\hline 23 & white spirit & SRLI 1.0 & 8.4246 \\
\hline 24 & xylene & 3 & 14.4333 \\
\hline 25 & kerosene & SRLI 1.2 & 0.8790 \\
\hline 26 & wood dust & SRLI 0.1 & 1.1235 \\
\hline 27 & PSK dust 20-70 \% & 3 & 2.2696 \\
\hline 28 & metal dust & SRLI 0.1 & 1.2969 \\
\hline 29 & PSK dust $>70 \%$ & 3 & 0.3687 \\
\hline 30 & abrasive metal dust & SRLI 0.4 & 1.5385 \\
\hline 31 & fiberglass dust & SRLI 0.06 & 0.3531 \\
\hline 32 & fiberglass plastic dust & SRLI 0.06 & 2.8357 \\
\hline 33 & phenolic dust & SRLI 0.05 & 1.6414 \\
\hline 34 & asbestos-containing dust & 1 & 0.0755 \\
\hline 35 & CEM dust & SRLI 0.04 & 0.0488 \\
\hline 36 & FR-2 dust & SRLI 0.1 & 2.7347 \\
\hline 37 & ethyltaluene & SRLI 0.7 & 0.3484 \\
\hline 38 & ozone & 1 & 0.00276 \\
\hline 39 & aluminum oxide & 2 & 0.01306 \\
\hline 40 & zinc oxide & 3 & 0.1295 \\
\hline 41 & copper oxide & 2 & 0.1305 \\
\hline 42 & vanadium pentoxide & 1 & 0.000647 \\
\hline 43 & epichlorohydrin & 2 & 0.1687 \\
\hline 44 & hydrochloric acid & 2 & 0.2593 \\
\hline 45 & ammonia & 4 & 0.00064 \\
\hline 46 & acetic acid & 3 & 0.06096 \\
\hline 47 & chromium anhydride & 1 & 0.90752 \\
\hline 48 & sodium hydroxide & SRLI 0.01 & 0.8802 \\
\hline 49 & phosphoric acid & SRLI 0.02 & 0.00030 \\
\hline 50 & nickel sulfate & 1 & 0.00343 \\
\hline 51 & boric acid & 3 & 0.00857 \\
\hline 52 & nitric acid & 2 & 0.03092 \\
\hline 53 & vinyl chloride & SRLI 0.005 & 0.000001 \\
\hline 54 & sodium carbonate & SRLI 0.04 & 0.12576 \\
\hline 55 & trisodium phosphate & SRLI 0.1 & 0.25155 \\
\hline 56 & sodium chloride & SRLI 0.15 & 0.85760 \\
\hline 57 & copper sulfate & 2 & 0.01742 \\
\hline 58 & potassium carbonate & 4 & 0.01742 \\
\hline 59 & tin sulfate & 3 & 0.00311 \\
\hline
\end{tabular}

Note: information on the materials of the «KhEMP» SE [9]; SRLI - safe reference level of impact 
Concentration of wastewater pollutants

\begin{tabular}{|c|c|c|c|c|}
\hline No. & Name of substance & $\begin{array}{c}\text { Concentration of the substance } \\
\text { in wastewater, } \mathrm{mg} / \mathrm{l}\end{array}$ & $\begin{array}{c}\text { Permissible concentration of substances } \\
\text { in wastewater, mg/l }\end{array}$ & $\begin{array}{c}\text { The mass of the substance } \\
\text { discharged, kg/year }\end{array}$ \\
\hline 1 & $\mathrm{pH}$ & 7.7 & $6.5-9.0$ & - \\
\hline 2 & dry residue & 702 & - & 58700.1 \\
\hline 3 & suspended substances & 78 & 400 & 1050.6 \\
\hline 4 & chlorides & 145.4 & 350 & 7142.8 \\
\hline 5 & sulfates & 105.4 & 350 & 8520.7 \\
\hline 6 & oil products & 1.95 & 5 & 142.05 \\
\hline 7 & iron & 2.1 & 5 & 141.1 \\
\hline 8 & ammonia nitrogen & 4.53 & 27 & 97.05 \\
\hline 9 & copper & 0.74 & 2 & 54.55 \\
\hline 10 & nickel & 0.03 & 0.1 & - \\
\hline
\end{tabular}

Note: information on the materials of the "KhEMP» SE [9]

Table 3

Characteristics of waste generated at the enterprise

\begin{tabular}{|c|c|c|c|c|c|}
\hline No. & Name of waste & $\begin{array}{l}\text { Technological process } \\
\text { of education care }\end{array}$ & $\begin{array}{l}\text { Hazard } \\
\text { class }\end{array}$ & $\begin{array}{c}\text { Amount of waste, } \\
\text { pcs } / t / \text { year }\end{array}$ & Disposal direction \\
\hline 1 & $\begin{array}{l}\text { Used mercury-containing fluorescent } \\
\text { tubes }\end{array}$ & \begin{tabular}{|l|} 
Lighting and operating instructions \\
SNTP 11-4-79
\end{tabular} & 1 & 1000 & Rent for disposal by specialized companies \\
\hline 2 & Spent lead-free battery plates & Motor transport & 1 & 0.909 & Rent for disposal by specialized companies \\
\hline 3 & $\begin{array}{l}\text { Slag of non-ferrous metals and alloys } \\
\text { containing lead }\end{array}$ & Non-ferrous metal processing & 1 & 11.410 & Sent to scrap metal collection plants \\
\hline 4 & Waste electrolyte acid battery & Motor transport & 2 & 2.730 & Neutralized \\
\hline 5 & Dil waste, engine oils & Motor transport & 2 & 1.000 & Accumulation \\
\hline 6 & Polishing waste & Production of electrical equipment & 3 & 0.500 & Landfill in the Derhachi (Ukraine) \\
\hline 7 & Tanned rags (textiles) & Metal machining & 3 & 0.500 & Landfill in the Derhachi (Ukraine) \\
\hline 8 & Aluminum waste & $\begin{array}{l}\text { Production of electrical equipment. } \\
\text { Metal machining }\end{array}$ & 3 & 7.000 & Sent to scrap metal collection plants \\
\hline 9 & Copper waste & $\begin{array}{l}\text { Production of electrical equipment. } \\
\text { Metal machining }\end{array}$ & 3 & 100.00 & Sent to scrap metal collection plants \\
\hline 10 & Tin waste & $\begin{array}{l}\text { Production of electrical equipment. } \\
\text { Metal machining }\end{array}$ & 3 & 2.000 & Sent to scrap metal collection plants \\
\hline 11 & $\begin{array}{l}\text { Ferrous metal waste containing iron } \\
\text { and its compounds }\end{array}$ & $\begin{array}{l}\text { Production of electrical equipment. } \\
\text { Metal machining }\end{array}$ & 3 & 5000.000 & Sent to scrap metal collection plants \\
\hline 12 & $\begin{array}{l}\text { Sludge after reagent and electroco- } \\
\text { agulation treatment }\end{array}$ & $\begin{array}{l}\text { Production of electrical equipment. } \\
\text { Metal machining }\end{array}$ & 3 & 0.588 & Landfill in the Derhachi (Ukraine) \\
\hline 13 & $\begin{array}{l}\text { Solvent compound: toluene, xylene, } \\
\text { white spirit }\end{array}$ & Electroplating wastewater treatment & 3 & in fact & Reapplied for the preparation of primers \\
\hline 14 & Used battery housings & Machine manufacturing & 3 & 2.730 & Landfill in the Derhachi (Ukraine) \\
\hline 15 & Sludge, emulsion & Motor transport & 3 & 3.333 & Accumulation. natural drying \\
\hline 16 & Waste materials (resin waste) & $\begin{array}{l}\text { Production of electrical equipment. } \\
\text { Metal machining }\end{array}$ & 3 & 13.158 & Landfill in the Derhachi (Ukraine) \\
\hline 17 & FR-2, CEM waste & Production of impregnation machines & 4 & 3.333 & Landfill in the Derhachi (Ukraine) \\
\hline 18 & $\begin{array}{l}\text { Waste foundry mixtures without heavy } \\
\text { metals }\end{array}$ & Making negative boards & 4 & 10.000 & $\begin{array}{l}\text { They are used to repair roads, territories } \\
\text { and avoid ice in winter }\end{array}$ \\
\hline 19 & Abrasive metal dust & Foundry & 4 & 1.630 & The accumulation is exported to the landfill \\
\hline 20 & Spent refractory brick & Gas cleaning & 4 & 2.300 & Landfill in the Derhachi (Ukraine) \\
\hline 21 & Wood shavings and dust & Foundry & 4 & $\begin{array}{c}178.287 \\
5.357\end{array}$ & Transmitted to the public \\
\hline 22 & Tires with steel cord & Woodworking. gas cleaning & 4 & 1.000 & Rent for disposal by specialized companies \\
\hline 23 & Waste paper & vehicle maintenance & 4 & 200.000 & Rent for disposal by specialized companies \\
\hline 24 & Garbage from the territory & Finished Product Packaging & 4 & 20.000 & Landfill in the Derhachi (Ukraine) \\
\hline
\end{tabular}

Note: information on the materials of the "KhEMP» SE [9] 
Thus, it is possible to draw the following conclusion that the following types of waste are generated at the enterprise:

- foundry slags;

- petroleum products;

- various kinds of solvents;

- sludge neutralization of spent solutions;

- waste solutions of various kinds of galvanic production;

- waste primers, enamels, putties;

- dishes contaminated with chemicals;

- wastewater of hydraulic locks of the painting chambers;

- waste metal machining;
- fluorescent lamps;

- wood shavings;

- garbage from the territory.

\section{Research results and discussion}

To reduce dust emissions at the «KhEMP» SE there are 20 gas treatment plants, including:

1) dust precipitation chambers;

2) cyclones;

3) filters and hydraulic filters.

Table 4 presents the characteristics of gas treatment plants (GTP).

Table 4

Characteristics of gas treatment plants

\begin{tabular}{|c|c|c|c|c|c|c|}
\hline \multirow{2}{*}{ No. } & \multirow{2}{*}{ GTP name } & \multicolumn{2}{|c|}{ Pollutant } & \multirow{2}{*}{ Entrance, $\mathrm{m}^{2} / \mathrm{m}^{3}$} & \multirow{2}{*}{ Treatment efficiency } & \multirow{2}{*}{ Exit, $\mathrm{m}^{2} / \mathrm{m}^{3}$} \\
\hline & & Code & Name & & & \\
\hline 1 & Dust chamber & 10414 & Metal dust & 21.31 & 69.5 & 6.50 \\
\hline 2 & TsN-15 cyclone (Russian Federation) & 2915 & Fiberglass dust & 17.42 & 55.8 & 7.70 \\
\hline 3 & Dust chamber & 10431 & Abrasive metal dust & 4.15 & 51.8 & 2.00 \\
\hline 4 & $\begin{array}{l}\text { VNINOT No. } 7 \text { cyclone (Russian Fed- } \\
\text { eration) }\end{array}$ & 10414 & Metal dust & 12.36 & 72.0 & 3.46 \\
\hline 5 & TsN-15 cyclone (Bussian Federation) & 10431 & Abrasive metal dust & 53.13 & 76.0 & 12.75 \\
\hline 6 & $\begin{array}{l}\text { VNINOT No. } 7 \text { cyclone (Russian Fed- } \\
\text { eration) (2 pcs.) }\end{array}$ & 10414 & Metal dust & 61.54 & 87.0 & 8.00 \\
\hline 7 & BC cyclone (Russian Federation) & 10678 & Phenolic dust & 18.56 & 68.9 & 5.77 \\
\hline 8 & BC cyclone (Russian Federation) & $\begin{array}{l}10036 \\
2916\end{array}$ & $\begin{array}{c}\text { FR-2 dust } \\
\text { Fiberglass dust }\end{array}$ & $\begin{array}{l}49.14 \\
49.14\end{array}$ & $\begin{array}{l}67.6 \\
67.6\end{array}$ & $\begin{array}{l}15.92 \\
15.92\end{array}$ \\
\hline 9 & ВС cyclone (Russian Federation) & 10678 & Phenolic dust & 42.70 & 71.9 & 12.00 \\
\hline 10 & BC cyclone (Russian Federation) & 10678 & Phenolic dust & 1.57 & 68.1 & 0.44 \\
\hline 11 & BC cyclone (Russian Federation) & $\begin{array}{l}10036 \\
2916\end{array}$ & $\begin{array}{c}\text { FR-2 dust } \\
\text { Fiberglass dust }\end{array}$ & $\begin{array}{l}63.29 \\
63.29\end{array}$ & $\begin{array}{l}68.4 \\
68.4\end{array}$ & $\begin{array}{l}20.00 \\
20.00\end{array}$ \\
\hline 12 & TsN-15 cyclone (Russian Federation) & 10368 & Asbestos dust & 48.86 & 86 & 6.84 \\
\hline 13 & TsN-15 cyclone (Bussian Federation) & 10431 & Abrasive metal dust & 163.54 & 77.4 & 36.96 \\
\hline 14 & Hydraulic filters & $\begin{array}{l}2752 \\
11510\end{array}$ & $\begin{array}{l}\text { White spirit } \\
\text { Aerosal }\end{array}$ & $\begin{array}{l}63.70 \\
19.74\end{array}$ & $\begin{array}{l}18.1 \\
53.6\end{array}$ & $\begin{array}{c}45.80 \\
9.16\end{array}$ \\
\hline 15 & Hydraulic filters & $\begin{array}{c}2752 \\
2750 \\
616 \\
11510\end{array}$ & $\begin{array}{c}\text { White spirit } \\
\text { Solvent } \\
\text { Xylene } \\
\text { Aerosal }\end{array}$ & $\begin{array}{l}75.21 \\
66.95 \\
65.30 \\
26.82\end{array}$ & $\begin{array}{l}17.7 \\
17.7 \\
17.7 \\
56.0\end{array}$ & $\begin{array}{l}61.90 \\
55.10 \\
53.74 \\
11.80\end{array}$ \\
\hline 16 & TsN-15 cyclone (Russian Federation) & $\begin{array}{l}10036 \\
2716\end{array}$ & $\begin{array}{c}\text { FR-2 dust } \\
\text { Fiberglass dust }\end{array}$ & $\begin{array}{l}199.79 \\
199.79\end{array}$ & $\begin{array}{l}81.2 \\
81.2\end{array}$ & $\begin{array}{l}37.56 \\
37.56\end{array}$ \\
\hline 17 & Hydraulic filters & $\begin{array}{c}2752 \\
2750 \\
616 \\
11510\end{array}$ & $\begin{array}{l}\text { White spirit } \\
\text { Solvent } \\
\text { Xylene } \\
\text { Aerosol }\end{array}$ & $\begin{array}{l}44.86 \\
3.26 \\
7.58 \\
9.43\end{array}$ & $\begin{array}{l}21.4 \\
21.4 \\
21.4 \\
56.5\end{array}$ & $\begin{array}{l}35.26 \\
2.56 \\
5.96 \\
4.10\end{array}$ \\
\hline 18 & Fiber filters & 203 & $\begin{array}{c}\text { White spirit } \\
\text { Solvent } \\
\text { Xylene } \\
\text { Aerosol }\end{array}$ & 0.0191 & 57.0 & 0.0082 \\
\hline 19 & Dust chamber & 10293 & Wood dust & 75.0 & 92 & 6.00 \\
\hline 20 & $\begin{array}{l}\text { Gidroderevprom cyclone (Bussian Fe- } \\
\text { deration) }\end{array}$ & 10293 & Wood dust & 137.93 & 94.2 & 8.00 \\
\hline
\end{tabular}

Note: information on the materials of the «hhEMP» SE [9] 
As a result, it is possible to conclude that the gas treatment plants work well, with high treatment efficiency. All dust and gas cleaning equipment is in good condition, in fact, the efficiency of the equipment corresponds to the data recorded in the GTP passport.

In general, the main sources of pollution affect the environment as follows:

Atmosphere. «KhEMP» $\mathrm{SE}$ is a source of many substances that negatively affect the atmosphere. The main source of exposure to atmospheric air is carbon monoxide. The dispersion calculation is carried out according to the procedure [13]. This technique allows calculating the dispersion of impurities emitted into the atmosphere by single, point and linear, as well as a group of sources, taking into account the influence of the terrain.

The maximum value of the surface concentration of a harmful substance $\left(C_{m}\right)$ when a gas-air mixture is emitted from a single point source with a round mouth is achieved under adverse weather conditions at a distance of $\left(X_{m}\right)$ and is calculated by the formula:

$$
C_{m}=\frac{A \cdot M \cdot F \cdot m^{\prime} \cdot \eta}{H^{7 / 3}}
$$

where $A$ - coefficient depending on the temperature stratification of the atmosphere; $M$ - mass of the harmful substance emitted into the atmosphere per unit of time, g/s; $F$ - coefficient taking into account the sedimentation rate of harmful substances in the air; $m^{\prime}$ - coefficient taking into account the conditions of exit of the gas-air mixture from the mouth of the emission source; $H$ - height of emission source above ground level, $\mathrm{m} ; \eta$ - coefficient taking into account the influence of the terrain.

Because $\Delta T=T_{T}-T_{B}, \Delta T=0{ }^{\circ} \mathrm{C}$, the release source is cold.

To obtain the value of the coefficient $m^{\prime}$, let's determine the following intermediate coefficients:

$$
\omega_{m}^{\prime}=1.3 \cdot \frac{\omega_{G} \cdot D}{H},
$$

where $\omega_{G}$ - rate of release of the gas-air mixture from the pipe, $\mathrm{m} / \mathrm{s} ; D$ - diameter of the chimney pipe, $\mathrm{m}$.

$$
\begin{aligned}
& f_{e}=800\left(\omega_{m}^{\prime}\right)^{3}, \omega_{m}^{\prime}=1.107, \\
& f_{e}=1086.46, m^{\prime}=0.9 .
\end{aligned}
$$

Since $\omega_{m}^{\prime} \geq 0.5$ and $f_{e} \geq 100$, then let's use the formula (1) and obtain the values:

$$
C_{m}=0.0045 \mathrm{mg} / \mathrm{m}^{3} \text {. }
$$

Since the maximum concentration limit is lower than $\mathrm{MPC}_{\text {a.d. }}\left(3 \mathrm{mg} / \mathrm{m}^{3}\right)$, it is impractical to calculate carbon oxide dispersion.

Hydrosphere. The company uses water from the city water supply. The total actual discharge of normalized substances in the sewage network is $1668.598 \mathrm{~m}^{3} /$ day (418820 $\mathrm{m}^{3}$ /year). Of these, $191.198 \mathrm{~m}^{3} /$ day - household and $1179.47 \mathrm{~m}^{3} /$ day - production. The enterprise consumes $1770.75 \mathrm{~m}^{3}$ /day of water.

According to the permission for wastewater discharges approved by the Kharkivkommunochystvod utility company, the volume of wastewater at the enterprise is $46819 \mathrm{~m}^{3}$ /month.

The wastewater of the research object is discharged into the city sewer system through one outlet into the city sewer $d=200 \mathrm{~mm}$, which passes along Moskovsky Prospect of Kharkiv metro station and belongs to the Dykanevska biological treatment complex sewage basin $\left(Q=500,000 \mathrm{~m}^{3} /\right.$ day $)$.

Due to the fact that the company discharges waste water into the city sewer, there are no sources of impurities in water bodies.

In wastewater there is always a complex set of various pollutants. Wastewater of an enterprise containing substances that are practically not disposed of in urban wastewater treatment plants should be treated at local treatment facilities of industrial enterprises. The degree of such concentration, which, taking into account the diversion of industrial effluents in the sewerage network and the receiving reservoir, will ensure the water quality in it that meets the regulatory, that is, established by environmental authorities.

Groundwater. Potential sources of increased additional infiltration may be water-bearing communications, production with a «wet» process, treatment facilities for local wastewater treatment.

The model of additional infiltration nutrition is $3.6 \cdot 10^{-3} \mathrm{~m} /$ day. Sources of groundwater pollution at the industrial site are not found.

Since the regime network for monitoring groundwater pollution has not been implemented on the territory of the industrial site, it is not possible to conduct a predicted calculation of pollution.

Soil. Assessment of the aerogenic load on the soil is carried out for those indicators for which the value of background concentrations.

1. For the calculation, it is necessary to determine the concentration of sulfur and nitrogen:

$$
\begin{aligned}
& \frac{C_{\mathrm{NO}_{2}}}{C_{\mathrm{N}}}=\frac{M_{\mathrm{NO}_{2}}}{M_{\mathrm{N}}}, \\
& C_{\mathrm{N}}=\frac{14 \cdot 0.03}{14+16 \cdot 2}=0.009 \mathrm{mg} / \mathrm{m}^{3} ; \\
& \frac{C_{\mathrm{H}_{2} \mathrm{SO}_{4}}}{C_{\mathrm{S}}}=\frac{M_{\mathrm{H}_{2} \mathrm{SO}_{4}}}{M_{\mathrm{S}}}, \\
& C_{\mathrm{N}}=\frac{32 \cdot 0.001}{98}=0.0003 \mathrm{mg} / \mathrm{m}^{3} .
\end{aligned}
$$

2. Assessment of the load on the territory, which is created due to emissions of sources of air pollution, is determined by the formula:

$$
P=C_{s} \cdot V_{t} \cdot K
$$

where $C_{s}$ - concentration of the substance in the surface layer of the atmosphere, $\mathrm{mg} / \mathrm{m}^{3} ; V_{t}-$ fall rate, $V_{t}=0.125 \mathrm{~cm} / \mathrm{s}$; $K$ - coefficient of proportionality between units, $K=864$.

$$
\begin{aligned}
& P_{\mathrm{N}}=0.009 \cdot 0.125 \cdot 864=0.972 \mathrm{~kg} / \mathrm{m}^{3} \cdot \text { day } \\
& P_{\mathrm{S}}=0.0003 \cdot 0.125 \cdot 864=0.032 \mathrm{~kg} / \mathrm{m}^{3} \cdot \text { day } .
\end{aligned}
$$


3. The critical load on the soil is taken in accordance with international environmental standards:

$$
\begin{aligned}
& P_{\mathrm{N}}=2 \mathrm{t} / \mathrm{km}^{2} \cdot \text { year} ; \\
& P_{\mathrm{S}}=1 \mathrm{t} / \mathrm{km}^{2} \cdot \text { year. }
\end{aligned}
$$

4. The assessment is made by comparing the relative load of nitrogen and sulfur by calculating the total load:

$$
\begin{aligned}
& K_{i}=\frac{P i}{P_{k p i}}, \\
& K_{\mathrm{N}}=\frac{0.972 \cdot 365}{2000}=0.177 ; \\
& K_{\mathrm{S}}=\frac{0.032 \cdot 365}{1000}=0.012 ; \\
& \sum K_{i}=0.177+0.012=0.189<1 .
\end{aligned}
$$

Thus, the load on the soil does not exceed the permissible.

An approximate estimate of the specific load on the territory, which is created by the emissions of the enterprise with a radius of action of $R=0.84 \mathrm{~km}$, is determined by the formula:

$$
P_{i}=\frac{Q_{i} \cdot a \cdot K}{\pi \cdot R^{2}},
$$

where $Q_{i}$ - annual emission of the $i$-th component, t/year; $R$ - radius of the enterprise influence, $\mathrm{km} ; \alpha$ - coefficient characterizing the deposition of emissions in the zone of influence of the enterprise, $\alpha=0.4 ; K$ - transition coefficient -2.76 .

The specific load on the territory that is created by dust emissions:

$$
P_{\text {dust }}=\frac{1.17 \cdot 0.4 \cdot 2.76}{3.14 \cdot 0.84^{2}}=\frac{1.292}{2.21}=0.58 \mathrm{~kg} / \mathrm{km}^{2} \cdot \mathrm{day}
$$

Thus, the enterprise does not have a harmful effect on the soil.

\section{Conclusions}

Analyzing the emissions of harmful substances into the atmospheric air from the industrial site of the «KhEMP» SE, the following conclusion can be drawn: the concentrations of the ingredients emitted by the enterprise do not exceed the corresponding maximum permissible values. Emissions to the environment are local in nature and ensure a satisfactory state of the environment in the area where the facility is located and outside the sanitary protection zone.

It is recommended to timely monitor emissions of pollutants into the atmosphere by direct measurements at the source, to verify the efficiency of dust and gas treatment plants. An analysis of the initial data and the results obtained showed that at the moment the composition of contaminants in the wastewater of the enterprise does not exceed regulatory requirements. It can also be concluded that the electromechanical plant does not damage the soil. Given the non-agricultural nature of the use of land in the plant's sanitary protection zone, re-examination of soil for pollution, according to expert assessment with the existing production technology, is recommended not earlier than after 15-20 years. In order to reduce the technogenic impact of emissions on the environment, it is necessary to improve the production technology of the «KhEMP»SE.

The conducted studies will be useful for the implementation of environmental measures at enterprises of various industries that are sources of emissions of potentially hazardous substances.

\section{References}

1. Totai, A. V. et. al.; Totai, A. V., Korsakov, A. V. (Ed.) (2016) Ekologiia. Moscow: Iurait, 450.

2. Stolberg, F. V. (Ed.) (2000). Ekologiia goroda. Kyiv: Libra, 464.

3. Ekzempliarskii, N. S., Bagaeva, O. I., Brazgovka, O. V. (2015) Vliianie khimicheskikh veschestv na organizm cheloveka i ikh gigienicheskoe normirovanie. Aktualnye problemy aviacii $i$ kosmonavtiki, 11 (1), 767-768.

4. Krasnenok, I. S. (2015). Vidy vrednykh veschestv i ikh vozdeistvie na organizm cheloveka kak odin iz aspektov energosberezheniia. Epokha nauki, 4, 424-428.

5. Kelina, N. Iu., Bezruchko, N. V., Rubcov, G. K., Chichkin, S. N (2010). Ocenka vozdeistviia khimicheskogo zagriazneniia okruzhaiuschei sredy kak faktorariska dlia zdorovia cheloveka: analiticheskii obzor. Vestnik Tomskogo gosudarstvennogo pedagogicheskogo universiteta. Ekologiia, 3 (93), 156-161.

6. Du, W., Li, M. (2020). Assessing the impact of environmental regulation on pollution abatement and collaborative emissions reduction: Micro-evidence from Chinese industrial enterprises Environmental Impact Assessment Review, 82, 106382. doi: http:// doi.org/10.1016/j.eiar.2020.106382

7. Ganda, F. (2019). The impact of industrial practice on carbon emissions in the BRICS: a panel quantile regression analysis. Progress in Industrial Ecology, An International Journal, 13 (1), 84. doi: http://doi.org/10.1504/pie.2019.098813

8. Sanchez, L. F, Stern, D. I. (2015). Drivers of Industrial and Non-Industrial Greenhouse Gas Emissions. SSRN Electronic Journal. doi: http://doi.org/10.2139/ssrn.2741335

9. $D P \ll K h E M Z »$. Available at: https://khemz.kharkov.com

10. Dodatok No. 4. Pro zatverdzhennia Derzhavnykh sanitarnykh pravyl planuvannia ta zabudovy naselenykh punktiv (1996). Nakaz Ministerstva okhorony zdorovia Ukrainy. No. 173. 19.06.1996 Available at: https://zakon.rada.gov.ua/laws/show/z0379-96

11. Obobschennii perechen predelno dopustimykh koncentracii (PDK) i orientirovochno-bezopasnykh urovnei vozdeistviia (OBUV) vrednykh veschestv dlia vody rybokhoziaistvennykh vodoemov (1990). Moscow, 49.

12. Okhrana okruzhaiuschei sredy (1978). Leningrad, 506

13. OND-86. Metodika rascheta koncentracii v atmosfernom vozdukhe vrednykh veschestr, soderzhaschikhsia v vybrosakh predpriiatii. Available at: http://docs.cntd.ru/document/1200000112

Makarenko Dmytro, Senior Lecturer, Department of Chemistry Ecology and Technology Expertise, National Aerospace University «Kharkiv Aviation Institute»,Ukraine, e-mail:d.makarenko@khai.edu, ORCID: http://orcid.org/0000-0002-4672-2880 